order: Mr. W. H. Whiteley (E.A.I.S.R.) 'The Sentence and Sociology' and M. Coupez (I.R.S.A.C.) 'Le système tonal et les verbes en kinyarwanda et kirundi'; Dr. V. Neesen (I.R.S.A.C.) 'Le premier recensement par échantillonnage au Ruanda-Urundi en 1952' and Mrs. P. Reining (E.A.I.S.R.) 'Survey technique; the Bukoba survey'; Dr. A. W. Southall (E.A.I.S.R.) 'The study of social differentiation in Kampala' and Mr. H. S. Morris (E.A.I.S.R.) 'The structure of the Indian community in Kampala'; Dr. J. J. Maquet (I.R.S.A.C.) 'The cultural values of Ruanda' and Dr. E. H. Winter (E.A.I.S.R.) 'Life histories as a research tool'; Mr. A. B. Mukwaya (E.A.I.S.R.) 'Some problems of land tenure in Buganda' and Mr. J. Beattie 'The kibanja system of land tenure in Bunyoro'; M. D. Biebuyck (I.R.S.A.C.) 'Maternal uncles and sororal nephews among the Balega' and Dr. J. J. Maquet 'The Ruanda premise of inequality'; Mr. C. C. Wrigley (E.A.I.S.R.) 'African farming in Buganda' and Dr. A. W. Southall 'Belgian and British Administration in Alurland'; M. D. Biebuyck 'Exchanges taking place before, during, and after initiations to the Bwami association' and Mr. C. Reining 'The Zande settlement scheme'.

\title{
African Studies at Boston University
}

ON I July I953 an African Research and Studies Programme was formally inaugurated at Boston University. It is to be attached to the Boston University Graduate School and is under the direction of Dr. William O. Brown, Professor in the Department of Sociology and Anthropology, formerly Chief of the African Research Branch in the Department of State, Washington. The programme is designed to make a contribution to basic research and studies in the field of African affairs, and emphasis will be laid on the fundamental analysis of economic, social, political and technical factors as they relate to social change in contemporary Africa. Close liaison will be maintained with individual scholars and research organizations in the United States, Europe, and Africa.

Dr. Brown has long been a member, and a valued friend, of this Institute, and we welcome his appointment with its promise of fruitful collaboration between the new centre and the International African Institute in this important field of studies.

\section{Margaret Wrong Prize: Result of 1952 Competition}

THrs competition was open to competitors from Northern and Southern Rhodesia, Nyasaland, Portuguese East Africa, and Angola. The Silver Medal and prize of $£, s$ have been awarded to Oscar Ribas of Luanda, Angola, for a story in Portuguese entitled $A$ Praga.

For the 1953 competition manuscripts are invited from the Union of South Africa, the High Commission Territories and Madagascar. The language may be English, Afrikaans or French and manuscripts should reach the London office of the International Committee on Christian Literature for Africa, 2 Eaton Gate, London, S.W. I, before 31 December 1953.

\section{Recording Vernacular Languages in Nigeria}

Dr. HANS WOLFF, an American linguistic specialist, is travelling for twelve months in Nigeria under the auspices of UNESCO, in order to study and advise on the use of vernacular languages in education and literacy campaigns. Dr. Wolff is proposing to record little-known languages and devise orthographies for those not yet reduced to writing. 